\title{
鋏状化合物の解毒能に関する薬理学的研究 $(\mathrm{l})$
}

\author{
柴田章次 \\ (京都大学医学部薬理学教室) \\ (昭和31年11月12日受付)
}

緒 言

鉊中毒の解毒沉当つててれまで BAL，クエン酸ソーダ及びチオ硫酸りーダ等が使用されて来たにもかかか らず, その効果についてはとかく意見わ一致を欠゙、た。即ち BAL 亿関し Moeschlin \& Schechterman', Zeglion,

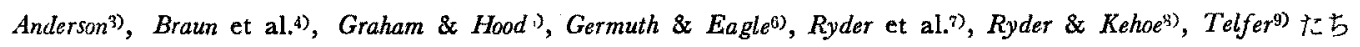

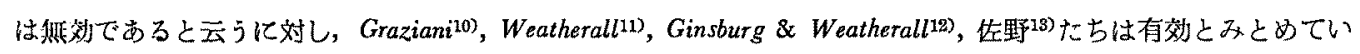

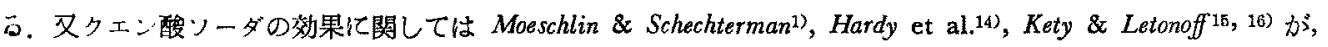
チオ硫酸ソーダの效果汇関しては Dennie \& McBride ${ }^{17)}$, Hegler18), Schmitt \& Lossie ${ }^{19)}$ たちが観察しているがい ずれもをれらの報告は決定的な結論を与えるものではない，しかし近年鉄状化合物たる Ca-EDTA 塩 (Monocalcium disodium ethylendiamine tetraacetate) の出現によつて鉛中毒の治蹽に非常な明るい見通しを与えたこ

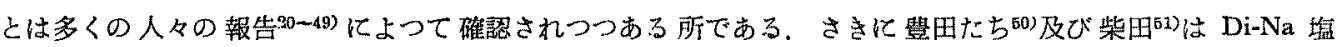
(Disodium ethylendiamine tetraacetate) の菂理作用及び毒性につき報告したが，ての Di-Na 塭は体内で血中

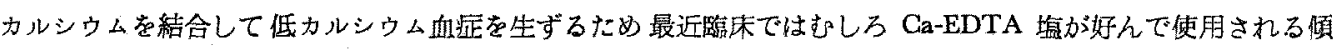

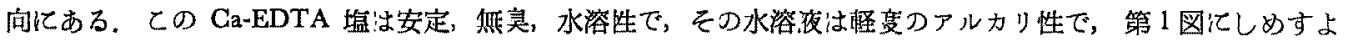
うに鉛と結合した場合 Pb-EDTA となり，非イオン性つ錯塩を形成する，陽イオンに対する安定度恒数，即ち<smiles>CCCC1CC(=O)OC12CN(CC(=O)O[Na])CCN2CC(=O)OC</smiles>
結合力はアルカリ金属 (Na，K) に対してもつ とも弱く，次いでアルカリ土類 $(\mathrm{Ca}, \mathrm{Mg}$ )，稀 土類の順之なり, 重金属 $(\mathrm{Cu}, \mathrm{Ni}, \mathrm{Pb})$ K対し てもつとも強い.したがつて路中毒に際して生 体に使用しても Ca-EDTA はカルシウムが鉙と の結合をさまだげるともなく爻低カルシウム 血症を生ずるととるなく，容易化 Pb-EDTA 老形成する。

そこで私は $\mathrm{BAL}$ ，タエン酸ソーダ，及び<smiles>O=C(CN1CCN(CC(=O)OC(=O)O[Na])CC1)O[Na]</smiles>

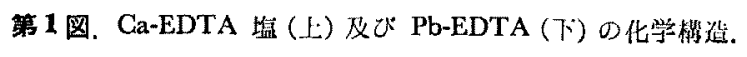
チオ硫酸ンーダの鉛中毒解毒能についての效果 を検討し，從来の諸説を統一するとともに， Ca-EDTA の效果を刍椧し，てれら四楽物につ いてその效力の比恔をするため以下の実験を行 つた.

\section{A. 性試 験}

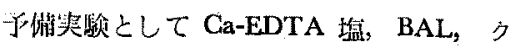




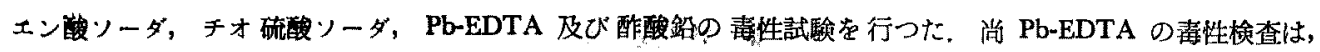
Ca-EDTA が鉛と体内で結合して Pb-EDTA となるから，その薄性を検する意味でわざわざ合成した品につい ておとなつた。

\section{実験材料及び実験方法}

実験動物には体重 12〜15gの成熟雄性マウスを使用し，10匹をもつて一群の契験を行つだ，樂物の 1 回投与 量仗0.5cc以内としていずれも腹腔内注射によつて与え，マウス体重10gに対し Ca-EDTA 塩 (帝国化学産業)

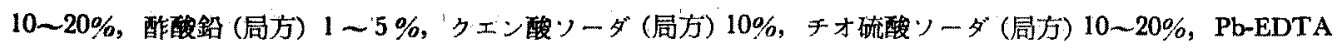

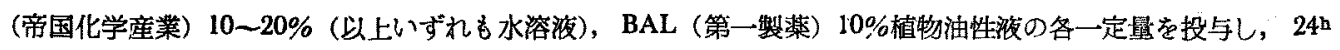

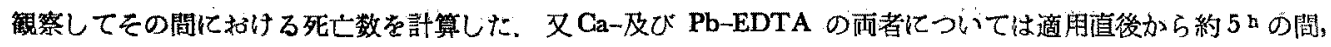
特て注意してその中書正状を篗察した，尚LD50つ計算には Litchfield-Wilcoxon 氏法を採用した。

\section{実 瑍成 維}

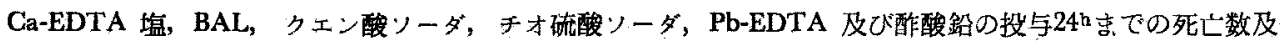
びてれら楽物つLD50は第 1 表に示す如くである.

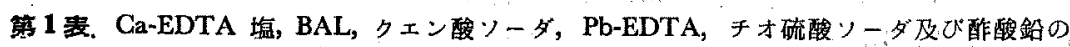
腹腔内注射によるマウス致死量。

\begin{tabular}{|c|c|c|c|c|c|c|}
\hline 薬 物 & Ca-EDTA 塩 & BAL & $\begin{array}{l}\text { クェン酸 } \\
y-\text { 多 }\end{array}$ & $\mid$ Fオ硫酸ソーダ & Pb-EDTA & 酢 酸 鉛 \\
\hline $\begin{array}{l}\text { 投与量 } \\
(\mathrm{mg} / 10 \mathrm{~g})\end{array}$ & $\begin{array}{llllll}100 & 80 & 70 & 40 & 10\end{array}$ & $\begin{array}{llllll}5 & 2.5 & 1 & 0.8 & 0.5\end{array}$ & 50302010 & $\begin{array}{lllllll}080 & 60 & 40 & 30 & 20 & 1\end{array}$ & $100806030 \quad 15$ & 107531 \\
\hline 死亡率(\%) & $\begin{array}{lllll}90 & 50 & 30 & 0 & 0\end{array}$ & $100 \quad 100 \quad 60 \quad 30$ & 10080402 & $080 \quad 60 \quad 30 \quad 10$ & $83.50 \quad 330$ & $100 \quad 90 \quad 8030 \quad 0$ \\
\hline $\begin{array}{l}\text { LD50 } \\
(\mathrm{mg} / 10 \mathrm{~g})\end{array}$ & $\begin{array}{c}76 \\
(63 \sim 92)\end{array}$ & $\begin{array}{c}0.96 \\
(1.4 \sim 0.6)\end{array}$ & $(27 \sim 14.8)$ & $\begin{array}{c}52 \\
(63.4 \sim 42.6)\end{array}$ & $\begin{array}{c}75 \\
(90 \sim 62.5)\end{array}$ & $\begin{array}{c}3.9 \\
(4.8 \sim 3.0)\end{array}$ \\
\hline
\end{tabular}

その内 Ca-EDTA 及び Pb-EDTA による毒性症状は殆んど同様で，いずれも70mg/kg以下の投与量では観 察時間内に特記すべき症状をみとめず，80mg/10g投与では 3 後動作の緩慢をきたしたが死亡ずるものはなかつ た。.しがし $100 \mathrm{mg} / \mathrm{kg}$ 投与群では $3 \mathrm{~b}$ 後に運動綏慢となり, やがて起立不能, 四肢伸展, 腹卧位となり, 外界の刺 激に対して㱠んど反応をしめさず，後肢の逃避反応 (Withdrawal reflex) は陰性であつた。. 更にその大部分は軽

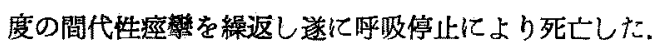

な枕參考までと BAL $1 \mathrm{mg} / \mathrm{kg}$ 以上の投与量についての 毒性症状を特記すると，投与10m後運動不安状態，

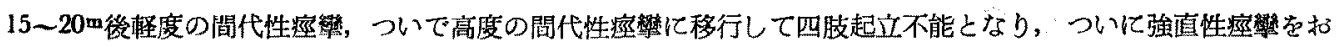
こし呼吸麻瘦で $122 \mathrm{~h}$ 以内に死しした，尚 BAL $0.8 \mathrm{mg} / \mathrm{kg}$ 及び $0.5 \mathrm{mg} / \mathrm{kg}$ 投与群では $5 \mathrm{~h}$ 以内に死亡する例は なかつた

\section{B. 急性鉛中毒に及ぼナ Ca-EDTA 埴、BAL，クエン蓜ンータ 及びチオ硫酸ンーダの影翌}

\section{実験村料及ひ実験力法}

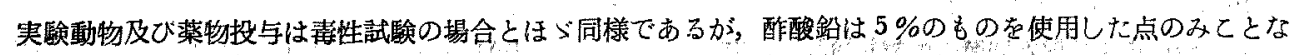

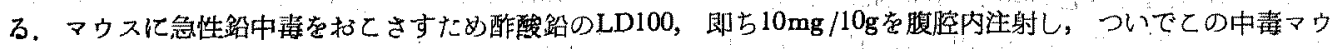

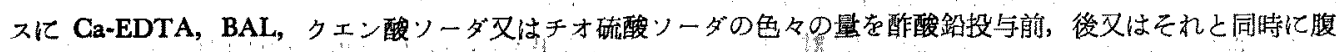

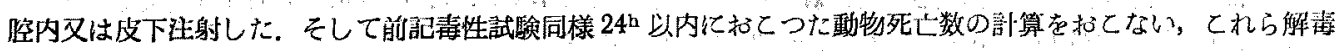

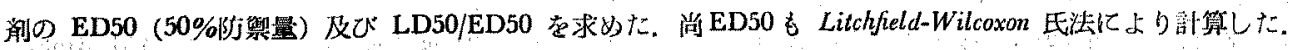




\section{䒠 成 杫}

\section{CO-EDTA}

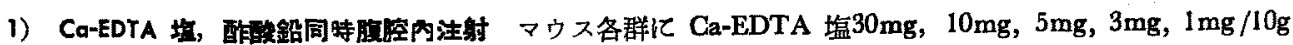

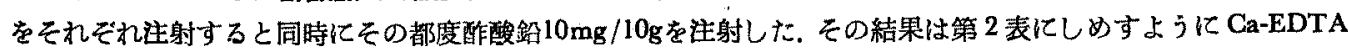
塩 $10 \mathrm{mg} / 10 \mathrm{~g}$ 上では死亡率は著明に低く，それ以下の投与量では急に高くなつた。

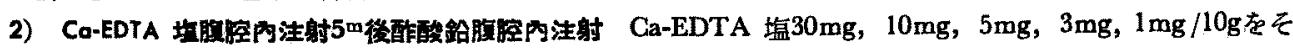
れぞれ注射して 5 m後酩酸鉊 $10 \mathrm{mg} / 10 \mathrm{~g}$ 注射した．第 2 表にしめすように Ca-EDTA 塩 30 - $10 \mathrm{mg} / \mathrm{kg}$ では死亡 率は低く $5 \mathrm{mg} / \mathrm{kg}$ 以下で急に高くなつた。

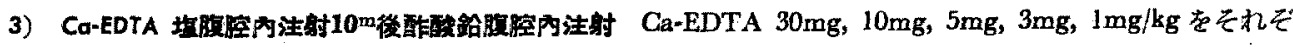
れ注射して 10 後酷酸鉛 $10 \mathrm{mg} / \mathrm{kg}$ を注射した，第 2 表にしめすように Ca-EDTA 塩 $10 \mathrm{mg} / \mathrm{kg}$ 以上では死亡率は 低く $5 \mathrm{mg} / \mathrm{kg}$ 以下で急倍くなつだ.

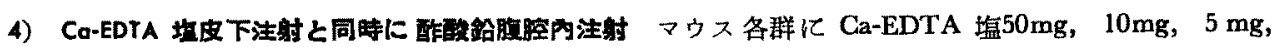
$3 \mathrm{mg} / \mathrm{kg}$ をそれぞれ皮下注射し，同時にその都度酶酸鈖 $10 \mathrm{mg} / \mathrm{kg}$ 注射した所，24a内内に全例死亡した。

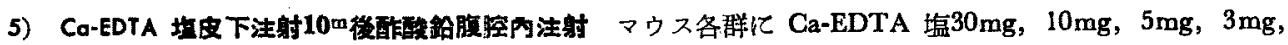

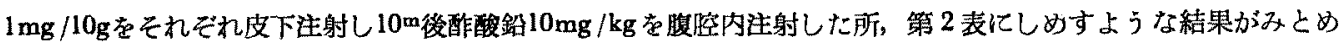

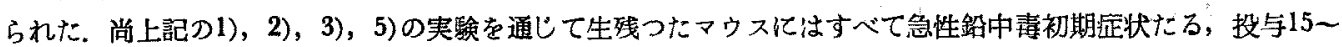
20 m後汇必発する四肢の震嶄はみとめられなかつた。

第 2 淁、Ca-EDTA 塩の鉛中毒防罢作用.

\begin{tabular}{|c|c|c|c|c|c|c|c|c|}
\hline \multicolumn{2}{|c|}{$\begin{array}{l}\text { 投 与量 } \\
(\mathrm{mg} / 10 \mathrm{~g})\end{array}$} & 30 & 10 & 5 & 3 & 1 & $\begin{array}{c}\text { ED50 } \\
(\mathrm{mg} / 10 \mathrm{~g}) \\
\end{array}$ & LD50/ED50 \\
\hline 死 & $\mathbf{A}$ & 0 & 20 & 40 & 80 & 100 & $4.4(6.6-2.9)$ & 17.2 \\
\hline L & B & 30 & 30 & 80 & 80 & 100 & $8.5(11.1 \sim 6.5)$ & 8.9 \\
\hline 率 & $\mathbf{C}$ & 40 & 40 & 70 & 90 & 100 & $11.5(21.8-6.0)$ & 6.6 \\
\hline$(\%)$ & D & 20 & 30 & 80 & 90 & 100 & $8.8(12.4 \sim 6.3)$ & 8.3 \\
\hline
\end{tabular}

註：A：Ca-EDTA 塩, 酢酸鉊同時腹腔内注射,

B : Ca-EDTA 塩腹腔内注射 $5^{\mathrm{m}}$ 後酢酸鉛腹腔内注射,

C : Ca-EDTA 塩腹腔内注射 $10 \mathrm{~m}$ 後酷酸鉊腹腔内注射,

D：Ca-EDTA 塩皮下注射 $10 \mathrm{~m}$ 後酷酸鉛腹腔内注射， 表中（）内数字は $5 \%$ 信頼限界.

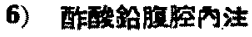
射 $5 \mathrm{~m}$ 後 Co-EDTA 程腹腔 可注射 マウ久各群に酶 酸鉛 $10 \mathrm{mg} / \mathrm{kg}$ 腹腔内注 射し, $5 \mathrm{~m}$ 後 Ca-EDTA 塩 $60 \mathrm{mg}, 30 \mathrm{mg}, 10 \mathrm{mg}$, $7 \mathrm{mg} / 10 \mathrm{~g}$ をそれそれ注射 した所，24h 以内に全例 死亡した。

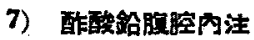

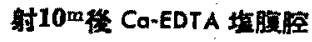
内注期 6)の場合と同様

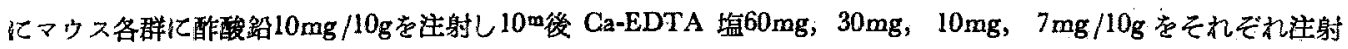
した所，24h以内に全例死亡した。

BAL

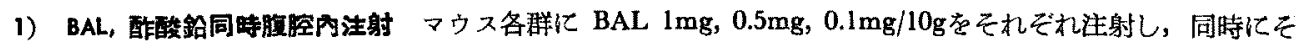

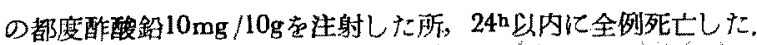

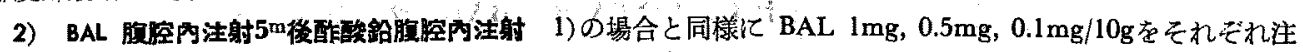

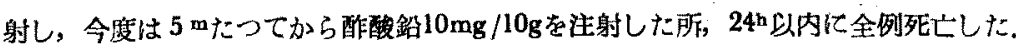

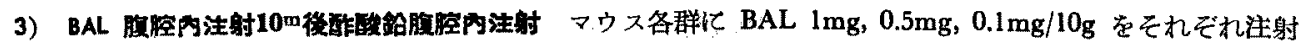
し，10m後酢酸鉛 $10 \mathrm{mg} / 10 \mathrm{~g}$ を注射した可, $24 \mathrm{~b}$ 以内に全例死亡した.

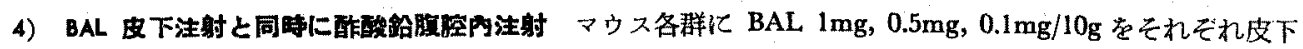
注射し，その都度酢酸鉛 $10 \mathrm{mg} / 10 \mathrm{~g}$ 注射した所， $24 \mathrm{~h}$ 以内に全例死しした。

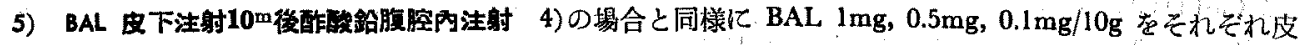

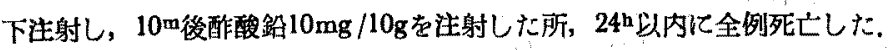

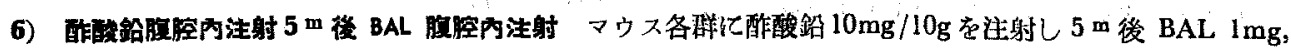


$0.5 \mathrm{mg}, 0.3 \mathrm{mg} / 10 \mathrm{~g}$ をそれぞ机注射した前，24h以内に全例死亡した。

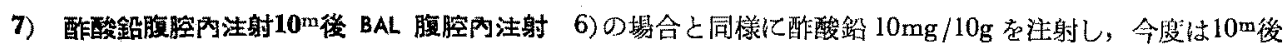
BAL $1 \mathrm{mg}, 0.5 \mathrm{mg}, 0.3 \mathrm{mg} / 10 \mathrm{~g}$ をれでれ注射した所，24h以内に全例死亡した。

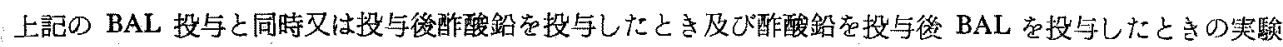

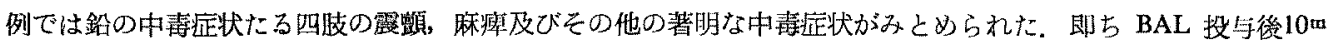

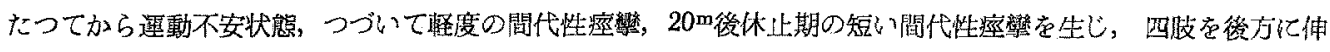

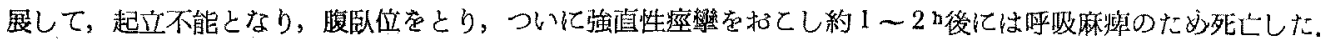
これらの症状は BAL $1 \mathrm{mg} / 10 \mathrm{~g}$ 以上を単独没投与したときの中表症状とよく類似している。

\section{クェン酸ソーダ}

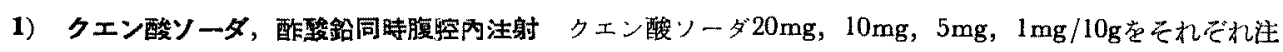
射し同時にその都度酷酸雓 $10 \mathrm{mg} / 10 \mathrm{~g}$ 注射した所, $24 \mathrm{n}$ 以内に全例死亡した。

2）クエン酸ソーダ腹腔内注射 5 後酶酸鉿腹腔內注射 1) の場合之同様にクエン酸ソーダ $20 \mathrm{mg}, 10 \mathrm{mg}$,

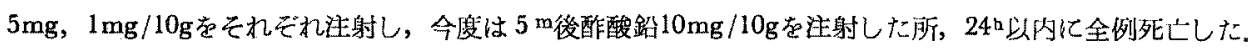

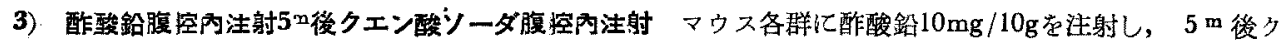
エン酸ソーダ $20 \mathrm{mg}, 10 \mathrm{mg}, 5 \mathrm{mg}, 1 \mathrm{mg} / 10 \mathrm{~g}$ 注射した所, $24 \mathrm{~h}$ 以内に全例死亡した。

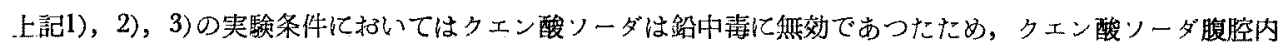

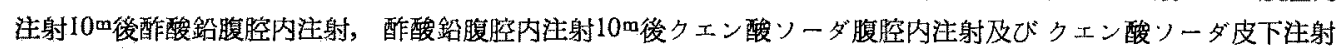

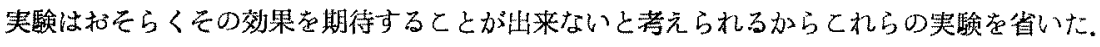

チオ硫酸ソーダ

1) チオ硫酸ソーダ，酷酸鉛同㭙腹悾內注射 マウス各群にチ才硫酸ソーダ $40 \mathrm{mg}, 30 \mathrm{mg}, 20 \mathrm{mg}, 10 \mathrm{mg}$, $5 \mathrm{mg} / 10 \mathrm{~g}$ をれでれ注射し，同時にそつ都曼醀酸鉛 $10 \mathrm{mg} / 10 \mathrm{~g}$ 注射した所，24n以内に全例死亡した。

2) チ才硫酸ソーダ腹腔内注射 5 後酷酸鉛腹腔內注射 マウス各群にチ才硫酸ソーダ $40 \mathrm{mg}, 30 \mathrm{mg}, 20 \mathrm{mg}$, $10 \mathrm{mg} / 10 \mathrm{~g}$ ををれぞれ注射し， $5 \mathrm{~m}$ 後酶酸鉛 $10 \mathrm{mg} / 10 \mathrm{~g}$ を注射した所， $24 \mathrm{~b}$ 以内に全例死亡した。

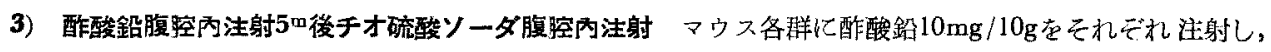
5 m後チオ硫酸ソーダを注射した所, $24 \mathrm{~h}$ 以内に全例死亡した。

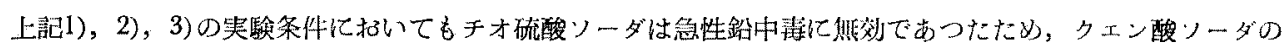

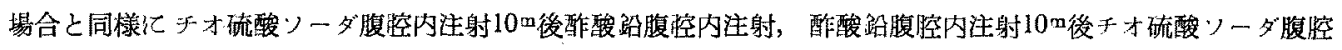

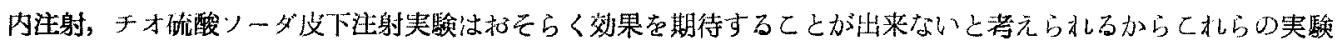
を省いだ。

\section{総括及び考按}

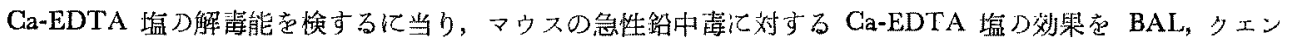

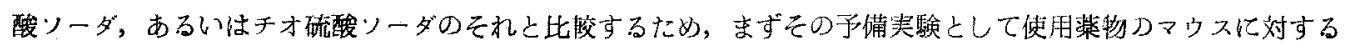
海性をしらべだ。

\section{1) 憲性試験}

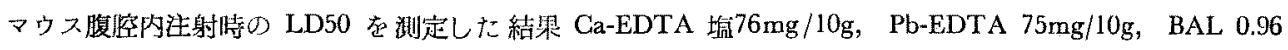
$\mathrm{mg} / 10 \mathrm{~g}$, タェン酸ソーダ $20 \mathrm{mg} / 10 \mathrm{~g}$, チ才硫酸ソーダ $52 \mathrm{mg} / 10 \mathrm{~g}$, 酶酸鉓 $3.9 \mathrm{mg} / 10 \mathrm{~g}$ であつた. Ca-EDTA 塩つ

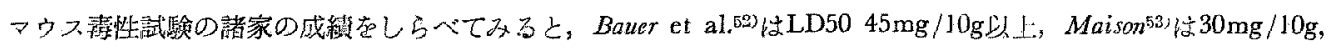

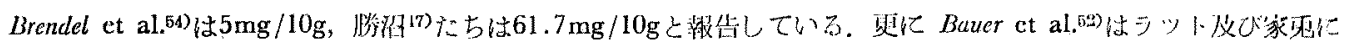

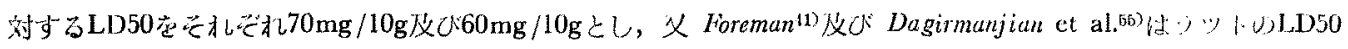

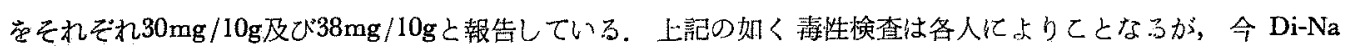

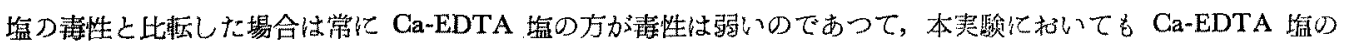

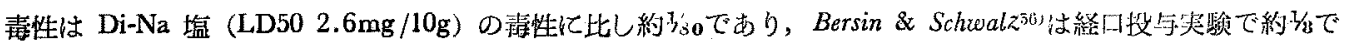

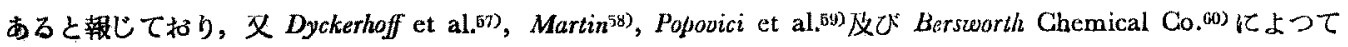




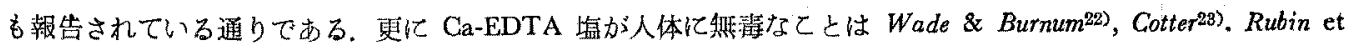

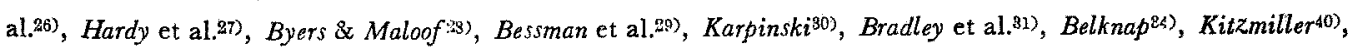

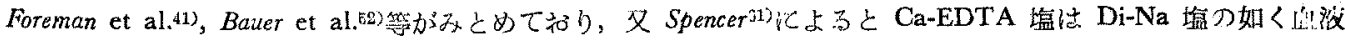

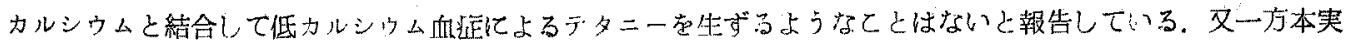

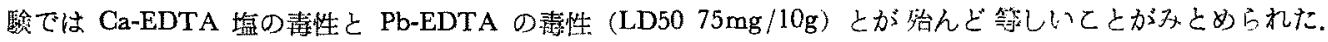

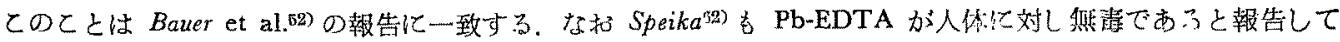

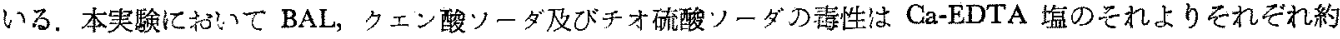

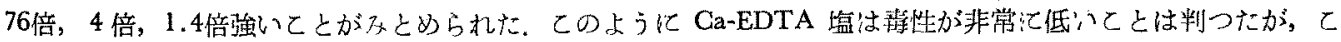

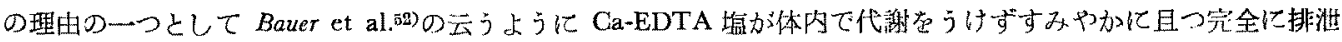
される事実を主要因子と見るべきであろう。

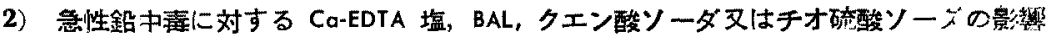

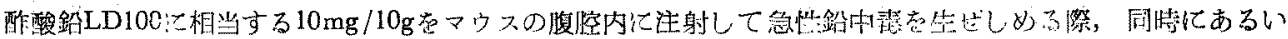

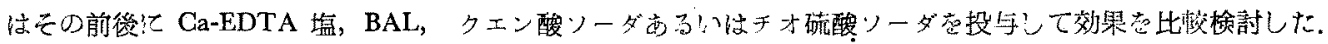

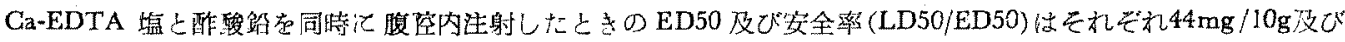

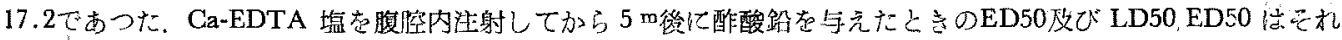

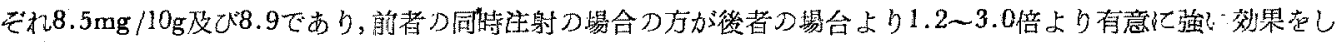

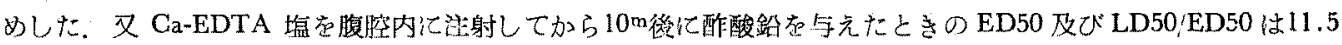

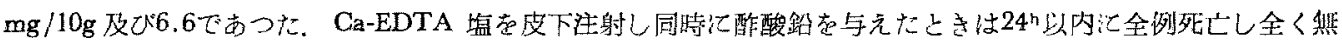

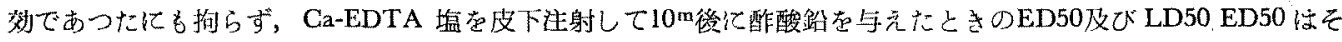

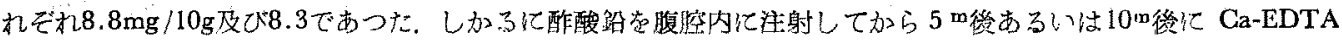

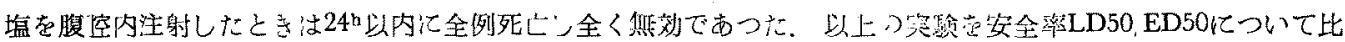

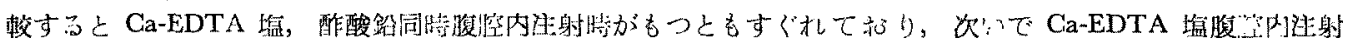

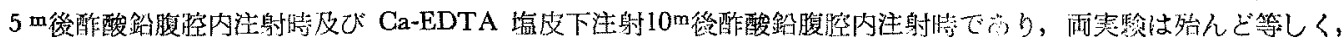

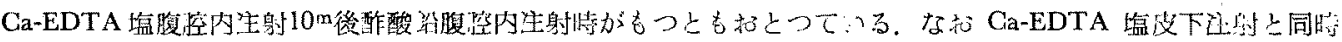

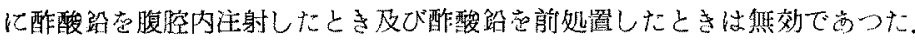

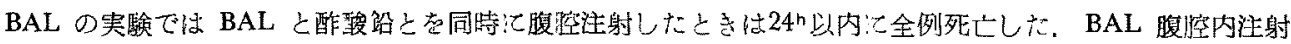

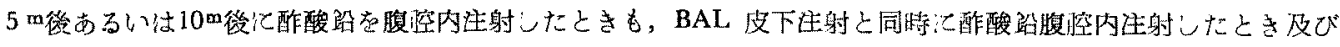

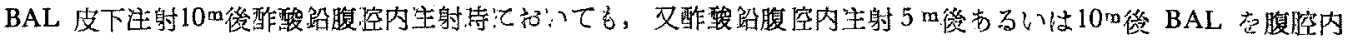

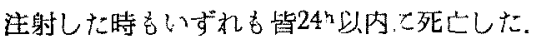

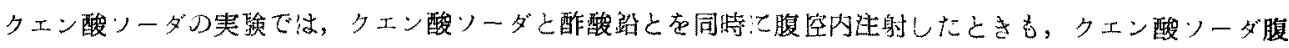

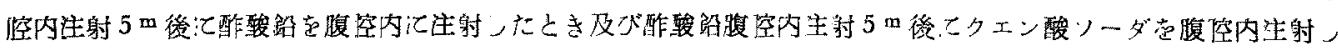
たときもいずれも皆24h以内て死亡した。

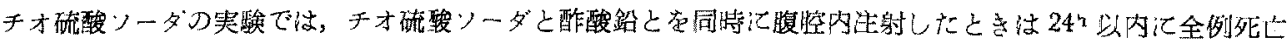

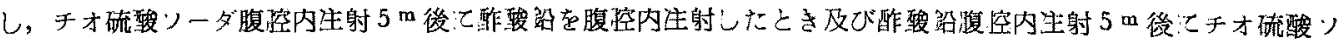

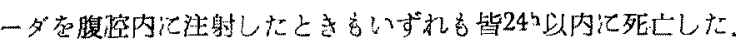

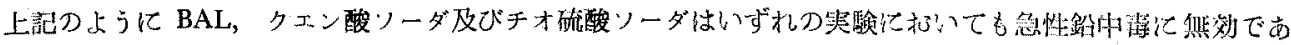
วt:.

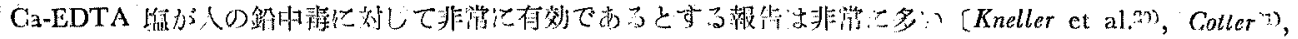

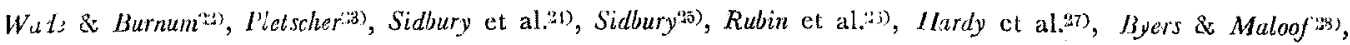

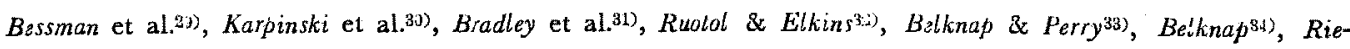

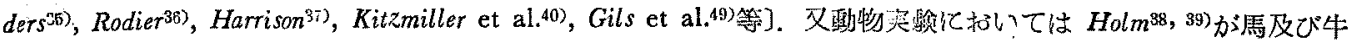

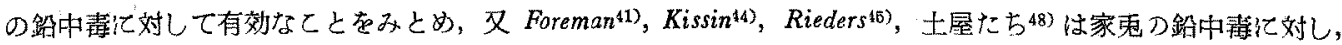

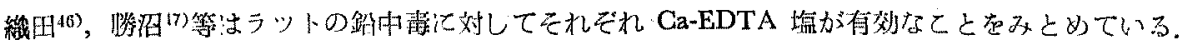

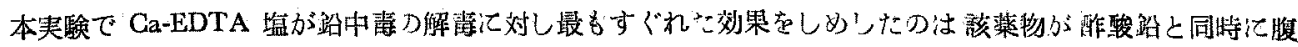


院内注射されたときではあつたが，Ca-EDTA 塩を皮下注射後酷酸鉛を腹腔内注射したときのように投与方法が

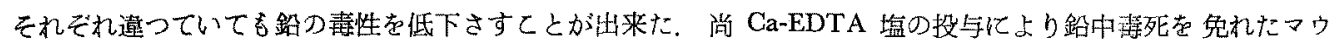

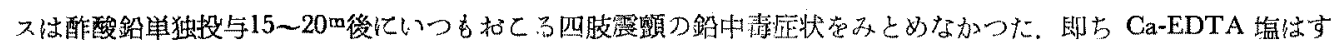

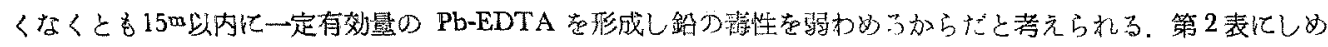
すよ5

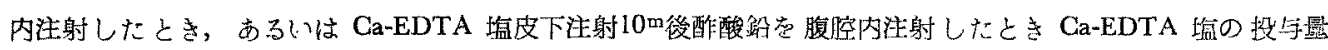

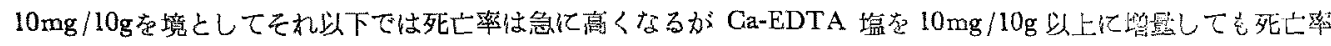

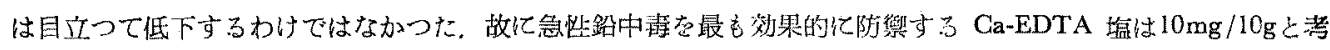

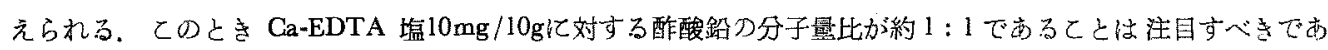

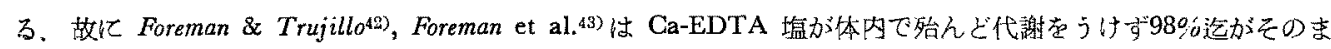

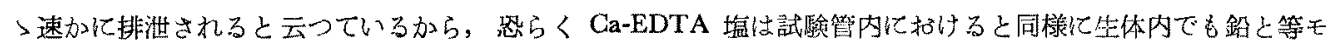

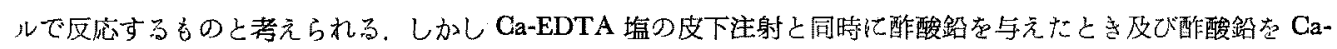

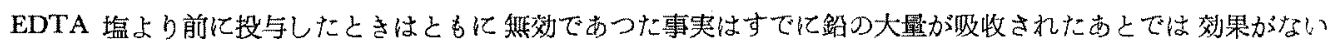

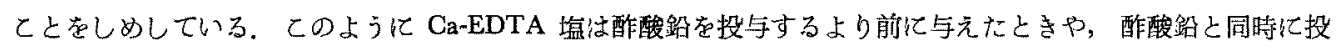

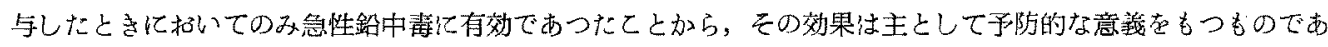
ろ゙と若えられる。

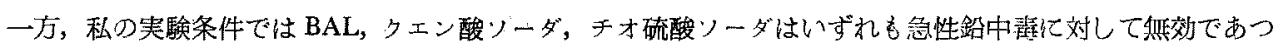

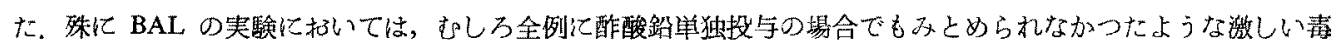

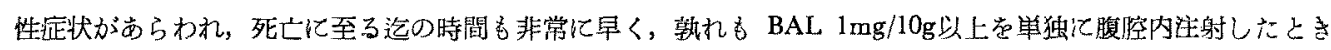

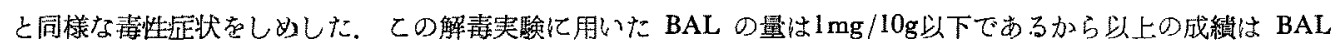

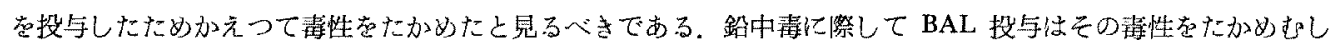

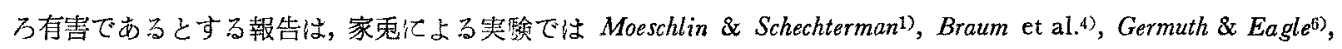

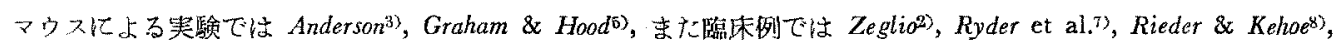

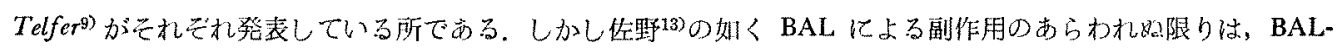
$\mathrm{Pb}$ の毒幽についてあまり問題にする必要はないとするもの，また家象鉛中毒に対する BALの治療效果者或程 度办とめている Graziani10), Weatherall ${ }^{11)}$, Ginsburg \& Weatherall19の妈き人々もないではない.

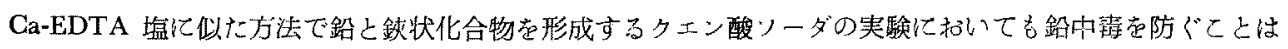

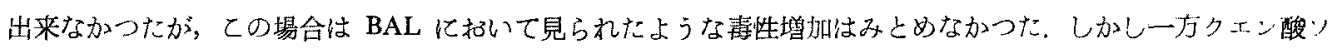

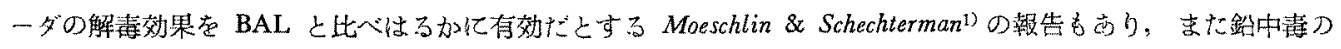

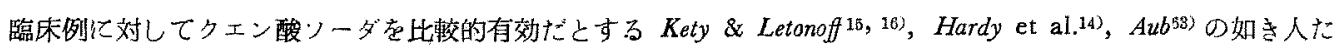

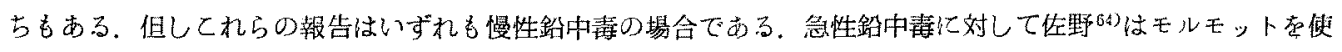

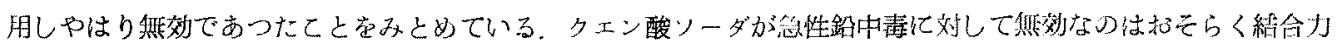
及び排渫速度が Ca-EDTA 㙁比して著しく劣るだめであろう。

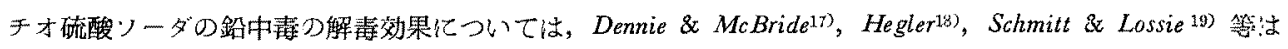

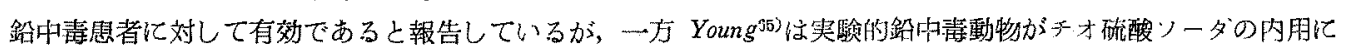

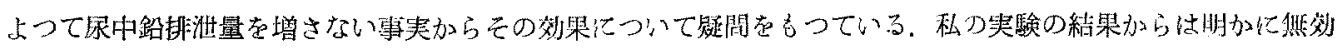
であな.

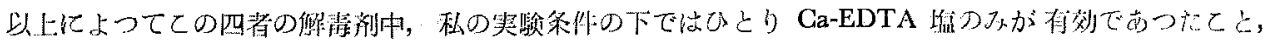

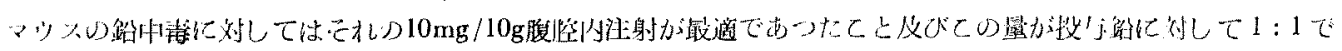
反応することか明かになつた。

\section{引用書 目}

1) Moeschlin \& Schechterman : Schweiz. Med. Wschr. 82, 1164 (1952).

2) Zsglio : Rassegna di med. indust. 18, 220 (1949). 
3) Anderson : Brit. J. Pharmacol. 4, 348 (1942).

4) Braun et al. : J. Pharmacol. 87, 119 (1946).

5) Graham \& Hood: Brit. J. Pharmacol. 3, 83 (1948).

6) Germuth \& Eagle: J. Pharmacol. \$2, 397 (1948).

7) Ryder et al. : Science 106, 63 (1947).

8) Ryder \& Kehoe : J. Lab. \& Clin. Med. 32, 1423 (1947).

9) Telfer: JAMA 135, 835 (1947).

10) Graziani : Folia med. 32, 467 (1949).

11) Weatherall: Brit. J. Pharmacol. 3, 137 (1948).

12) Ginsburg \& Weatherall: 同誌 3, 223 (1948).

13) 伀野: 圂民衛生 22, 266 (1953)。

14) Hardy et al. : Arch. Indust. Hyg. \& Occup. Med. 3, 267 (1951).

15) Kety \& Letonoff : Am. J. Med. Sc. 205, 406 (1943).

16) Kety \& Letonoff : Proc. Soc. Exper. Biol. \& Med. 46, 479 (1941).

17) Dennie \& McBride: JAMA 82, 2082 (1924).

18) Hegler : Dtsch. Med. Wschr. 51, 804 (1925).

19) Schmitt \& Lossie : Dtsch. Arch. Klin. Med. 182, 200 (1938).

20) Knel er et al. : New Eagland J. Med. 252, 338 (1955).

21) Cotter : JAMA 155, 906 (1954).

22) Wade \& Burnum : Ann. Int. Med. 42, 251 (1955).

23) Pletscher: Schweiz. Med. Wschr. 95, 128 (1955).

24) Sidbury et al. : Am. J. Med. 18, 932 (1955).

25) Sidbury : Proc. Soc. Exper. Biol. \& Med. 82. 226 (1953).

26) Rubin et al. : Science 117, 659 (1953).

27) Hardy et al. : JAMA 154, 1171 (1954),

28) Byers \& Malonf : Am. J. Dis. Child. 87, 559 (1954).

29) Bessman et al. : M. Ann. Dist. of Columbia 21, 312 (1952).

30) Karpinski et al. : Arch. Indust. Hyg. \& Occup. Med. 10, 312 (1954).

31) Bradley et al. : J. Pediat. 45, 297 (I954).

32) Routol \& Elkins: Arch. Indust. Hyg. \& Occup. Med. 9, 205 (1954).

33) Belknap \& Peery : 同誌 10, 530 (1954).

34) Belknap : Indust. Med. 21, 305 (1952).

35) Rieders: 同誌 2A, 195 (1955).

36) Rodier: Arch. Mal. Prof. 15, 210 (1954).

37) Harrison: Arch. Indust. Hyg. \& Occup. Med. 7, 139 (1953).

38) Holm et al. : J. Am. Vet. Med. A. 123, 383 (1953).

39) Holm et al. : 何誌 123, 528 (1953).

40) Kitzmiller et al. : Arch. Indust. Hyg. \& Occup. Med. 10, 312 (1954).

41) l'orcman: 间施: 7, 137 (1953),

42) Fureman \& Trujil'o: J. Lab. \& Clin. Med. 23, 566 (1951).

43) Foreman et al. : J. biol. Chem. 203, 1045 (1953).

46) Kissin: Arch. Indust. Hyg. \& Occup. Med. 7, 139 (1953).

45) Rieders: Fed. Proc. 13, 397 (1954).

46) 絔目：国民街坐 25，22(1956). 
47) 勝沼: 労做科学 31, 191 (1955).

48) 土屋：同誌 30, 211 (1954).

49) Giles et al. : Lancet 268, 183 (1955),

50) 豐田たち：日薬理范 52，1（1956).

51) 柴田：同誌 52, 113 (1956).

52) Bauer et al. : Fed. Proc. 11, 320 (1952).

53) Maison : Arch. Indust. Hyg. \& Occup. Med. 7, 139 (1953).

54) Brendel et al. : J. Am. Pharmaceut. Assoc. Sci. Ed. 42, 123 (1953).

55) Dagirmanjian et al. : J. Pharmacol. \& Exper. Therap. 117, 20 (1956).

56) Bersin \& Schwalz: Schweiz. Med. Wschr. 83, 765 (1953).

57) Dyckerhoff et al.: Z. ges. exper. Med. 110, 412 (1942).

58) Martin : Meeting A.C.S., Abstracts 117, 16c (1949).

59) Popovici et al.: Proc. Soc. Exper. Biol. \& Med. 74, 415 (1950).

60) Bersworth Chemical Co. : Pharmacology, Physiology, Biochemistry \& Toxicity of Versens Framingham, Mass. (1952).

61) Spencer et al. : J. Cliñ. Invest. 31, 1023 (1952).

62) Speika: Arch. internat. Pharmacodyn. 101, 488 (1955).

63) Aub : JAMA 104, 87 (1935).

64) 传野: 国它衛生 22, 276 (1953).

65) Young: J. Lab, \& Clin. Med. 13, 622 (1927). 